\title{
THE POLITICAL AND SOCIAL LANGUAGE OF INDONESIAN MUSLIMS: THE CASB OF AL-MUSLIMUN
}

\author{
Howard M. Federspiel
}

\section{Introduction}

There is a stereotype long held in the West and in the Arabic world that Islam in Southeast Asia is lacking in depth and commitment to general principles of Islamic belief and practice. Western scholarly and nonscholarly writings about Southeast Asia over the past century have usually spoken of Islam's accommodation as it encountered peoples influenced by animism, Hinduism, and Buddhism. 1 Most studies that appeared up until the 1940s, while not denying the significant impact of Islam and the existence of some pious Muslims in the region, presented Islam in Southeast Asia as hopelessly mixed with local cultural practices and out of step with more purist forms in the Middle East. The trend was reinforced by certain Indonesian nationalists in the second quarter of the twentieth century who were persuaded that Islam's dominance in the sixteenth and seventeenth centuries had harmed native political strength and created conditions favorable to the establishment of European colonialism. 2 In general this perception of a syncretic Islam prevailed among scholars East and West until the 1970s.

There were notable exceptions to such a perception, however. The work of Anthony Johns, ${ }^{3}$ Hamka, 4 and Aboebakar Atjeh, ${ }^{5}$ inter alia, argued that while many Muslims did accommodate their religion to the cultures of the region, a strain of purist Islam has maintained itself for several centuries. In

1. C. Snouck Hurgronje, Nederland en de Islam (Leiden: Brill, 1911), esp. pp. 23-25; Ph. S. Van Ronkel, "Islam," in Encyclopaedie van Nederlandsch-Indie, vol. 3 (Leiden: Brill, 1918), esp. pp. 171-72; R. O. Winstedt, The Malay Magician (London: Routledge, 1961), esp. pp. 81-102; Richard J. Wilkinson, The Peninsular Malays, vol. 1 (Leiden: Brill, 1906), pp. 1-81.

2. Bernhard Dahm, Sukarno and the Struggle for Indonesian Independence (Ithaca: Cornell University Press, 1969), p. 338.

3. A. H. Johns, "Aspects of Sufi Thought in India and Indonesia in the First Half of the Seventeenth Century," Journal of the Royal Asiatic Society Malayan Branch [henceforth JRASMB], 28, 1 (1955): 70-77, and "Malay Sufism as Illustrated in an Anonymous Collection of Seventeenth Century Tracts," JRASMB, 30, 2 (1957): 5-111.

4. Hamka [H. Abd. Malik Karim Amrullah], Ajahku (Jakarta: Widjaya, 1958).

5. Hadji Aboebakar Atjeh, Sedjarah Hidup K.H.A. Wahid Hasjim dan karangan tersiarnja (Jakarta: Panitya, 1957), and "Pengantar," Sedjarah Sufi dan Tasawwuf (Bandung: Tjerdas, 1962). 
fact, the rise of modernist Islam throughout the region in the first quarter of the twentieth century resulted from the efforts of individuals and organizations associated with that purist outlook. ' That outlook remains politically and socially important in Southeast Asia today.

It is with the purist strain of Islam that I am concerned here, and, accordingly, criteria for determining its characteristics will be outlined and tested. This study contends that these criteria will serve as a valid measure to determine the identification with Islam of individuals and associations through their statements, writings, and practices. By identifying the attitudes of those who are closely connected with their religion, we can begin to understand better the diversity of belief in Southeast Asia and study it beyond the realm of stereotype.

The criteria put forth here are not to determine who is a Muslim and who is not. That is a matter for the community of Muslims to establish itself, in the context of its own tradition. Rather, what is attempted is to study those staunch Muslims in Southeast Asia who are deeply concerned about commitment to their faith and to examine the attributes that identify many of them.

The study postulates four thesis statements about Muslim attributes in Southeast Asia. They are:

1. Enunciation of Islamic principles as elaborated in standard Islamic sources of Qur'an and Traditions (Ar: hadĩth), 7 and expanded by important theologians, mystics, and legalists associated with the religion. Generally, Muslims maintain that God (Ar: Alläh) is the Creator, that he has sent prophets, including Muhammad, and his Word (Ar: Qur'ān) to mankind for guidance. Belief and practice are necessary to fulfill God's direction. For the purposes of this study Islamic principles are those outlined in several standard studies of Islam: notably Fazlurrahman's Islam, and Gibb's, Mohammedanism.

2. Heavy use of Arabic to express religious values, including names, terms, terminologies, and scriptural quotations. Muslims are committed

6. See in particular, G. F. Pijper, "Het Reformisme in de Indonesische Islam," in Studien over de geschiedenis van de Islam in Indonesia, 1900-1950 (Leiden: Brill, 1977), pp. 97-145, and William R. Roff, The Origins of Malay Nationalism (New Haven: Yale University Press, 1967).

7. Foreign words in parentheses are Indonesian unless preceded by "Ar:" indicating they are Arabic terms transliterated into Roman script. Qur'an and Allah, as words commonly used in English, are used in the text with these spellings and are not otherwise marked. The spelling of Indonesian words throughout is that used in the $1950 \mathrm{~s}$.

8. Fazlurrahman, Islam (New York: Holt, Rinehart, 1966), and H. A. R. Gibb, Mohammedanism (London: Oxford University Press, 1953). References cited in this section on methodology are to standard works known internationally and held in high regard by Islamicists, whether Muslim or not. The principles of Islam outlined in these works are distilled from books on specific subjects by the theologians, jurists, and other Muslim writers working on Islamic belief and practice. The specific studies use specialized language, of ten are not available except in Arabic, and are not generally available in most university libraries in the West. Hence, standard works are used in this study. 
to the use of Arabic: 1) as an absolute requirement for the preservation and use of religious sources (i.e., Qur'an and Tradition of the Prophet); 2) as a carrier of the exposition of Islam in numerous books on law, philosophy, and mystical practice; 3) in terms used in description of religious thought and practice; and 4) in the recitation of prayer. These terms are further identified in Padwick, Muslim Devotions and Hughes, Dictionary of Islam.'

3. Attempts to put the Islamic principles into everyday use, particularly 1) those concerned with the importance of worship and religious obligation; and 2) in cases when other actions are not contrary to or outlawed by Islam sources. This is specifically reflected in the concept of divine law (Ar: shart'a). This concept demands the application of the principles of justice derived from sources that establish God's law among men. Worship ranks high on both scores. This definition rests on the fuller elaboration given in Juynboll, Handleiding tot de kennis van de Mohammedaansche wet and Khadduri and Liebesny, Law in the Middle East.10

4. Nonrecognition or condemnation of other viewpoints that challenge Islam's importance in society or state or otherwise detract from the importance of Islam. The concept of the community of believers (Ar: umma) is at work here. It is important to promote a unity of believers to close ranks against outsiders whose beliefs, practices, and values challenge those of Islam. Consequently, there is a refusal to recognize the validity of other viewpoints except as they conform to the general Islamic perception of how things should be. Accommodation with outsiders is limited in time and extent. This statement rests on the fuller explanation of attitudes clarified by Smith, Islam in the Modern World and Haykal, The Life of Muhammad.11

This article will examine material contained in the periodical Al-Muslimun between 1955 and 1959 to illustrate the foregoing assumptions. We already know from previous studies that the Persatuan Islam, the publisher of Al-Muslimun, is an Islamic society, acknowledged as firmly Islamic by members and critics alike and, as such, a study of its contents could be expected to deal directly with Muslim attitudes and would constitute a test of the validity of the indicators outlined above. Our examination can be expected to yield very positive results.

\section{Description of Al-Muslimun}

The magazine Al-Muslimun was published in Bangil, East Java between 1954 and 1960. During the first three and a half years issues appeared monthly, and over the next two and a half years numbers appeared irregularly. It had a total run of forty-five issues before it ceased publication.

9. Constance E. Padwick, Muslim Devotions (London: SPCK, 1961), and Thomas P. Hughes, A Dictionary of Islam (Labore: Premier, 1964).

10. Th. W. Juynboll, Handleiding tot de kennis van de Mohammedaanische Wet (Leiden: Brill, 1930), and Mejid Khadduri and Herbert Liebesny, Muslim Law in the Middle East (Washington: Middle East Institute, 1955).

11. Wilfred C. Smith, Islam in Modern History (Princeton: Princeton University Press, 1957), esp. Chapter 1, and Muhammad Husein Haykal, The Life of Muhammad (Cairo: Shorouk International, 1983). 
Al-Muslimun was the voice of one center of an Islamic association, named the Persatuan Islam, which had been in existence since 1923 and had played an important, but never dominant, role in Indonesian political activity in the two decades prior to World War II and in the parliamentary period of independent Indonesia (1950 to 1957). 12 The Persatuan Islam was not fully reflective of the wider Indonesian community that regarded Islam as important. Two differences are apparent. First was its association with Pan-Islamism and the corresponding deemphasis of Indonesian nationalism. Arguing that Muslims should concentrate on the unity and prosperity of all Muslims in whatever lands they were located, leaders of Persatuan Islam were prone to argue for promotion of Islamic values in Indonesia in accord with the wider Muslim world. In the prewar years this stance was expressed as antinationalism, but in the $1950 \mathrm{~s}$ Persatuan Islam accepted Indonesia as a political reality and emphasized guiding the nation toward being fully Islamic. This stress on Islam was more marked than among other Muslim assuciations in Indonesia, most of which were more favorably disposed towards nationalism. A second characteristic of Persatuan Islam was the dominance of Ahmad Hassan, a Tamil from Singapore who had immigrated as an adult to Indonesia in the 1920s. Learned in Islamic lore and concerned, like others around him, about colonialism, he justified his own participation in anticolonial activity on the basis of Islam rather than nationalism. His influence was still strong in the 1950 s and, significantly, his son, Abdulkadir Hassan, who was an editor of Al-Muslimun and was rising in prominence in the Persatuan Islam at this time, held similar views to those of his father. ${ }^{13}$

In a tradition of widely distributed and controversial publications issued by the Persatuan Islam, the form of Al-Muslimun most reflected Pembela Islam, 14 except that its stress on holy law was perhaps more pronounced. Al-Muslimun included articles, presented in serial form, that outlined the traditional sciences of religious investigation and knowledge; articles on the vitality of Islam in contemporary times; an editorial column that spoke to issues of politics, social conflict, and threat to the community; and a column called Sual-Djawab (question-response) that answered readers' questions about appropriate conduct in religious affairs and everyday life. It is the last item that we will return to as the chief point of investigation.

Materials for Al-Muslimun came from a variety of sources. Some sections were reprints of previously published pieces, usually from elsewhere in the Muslim world.1s The sections on Islamic sciences, the editorials, and the answers to readers' questions were produced by the editorial staff or someone else connected with the Persatuan Islam. In particular, Abdulkadir Hassan and Abdul Musa, the editor, seem to have prepared much of the material, including

12. Pijper, "Reformisme," pp. 122-24; H. M. Federspiel, The Persatuan Islam (Ithaca: Cornell University Modern Indonesia Project, 1970).

13. For a view of accommodation with non-Muslim principles, see Ruth T. McVey, "Faith as an Outsider: Islam in Indonesian Politics," in Islam in the Political Process, ed. James P. Piscatori (London: Cambridge University Press, 1983), pp. 199-221. For further information on Ahmad Hassan, see Howard M. Federspiel, "Islam and Nationalism," Indonesia 24 (October 1977): 39-47.

14. Pembela Islam (Bandung: Persatuan Islam, 1929-35).

15. Examples are articles by Sa'īd Ramadhān of the World Muslim Congress, Muhammad Asād, the prominent Indian Muslim writer, and Nasĩruddĩn Al-Albāní, a Syrian Muslim scholar. 
responses to readers' questions. Other Muslim contributors assisted from time to time.

The magazine was published monthly and probably had a circulation of several hundred copies. Advertisements indicate that it was sold at bookstores in various places on Java, Sumatra, Kalimantan, and Sulawesi, and in Singapore. A few copies apprently were sent to Syria, Pakistan, and Malaysia, as the masthead cited association with people in those countries. Although written in Bahasa Indonesia, the magazine made heavy use of terms from Arabic, a trend in keeping with Indonesian works on Islam, but less in line with the general development of Bahasa Indonesia at that time when the infusion of Javanese, Sanskrit, and Western terms was much more pronounced,16 Quotes in Arabic when citing Islam scripture were consistent with standard writings on Islamic sciences and used extensively in every issue.

\section{The Sual-Djawab Section: General Overview}

The Sual-Djawab section is especially relevant to this study because it reflects readers' concerns about the relationship of religion to their lives. Further, the answers indicate how the Persatuan Islam attempted to lay out a guide for concerned Muslims reflecting the association's understanding of the application of Muslim values to contemporary Indonesian society. Over the five years of publication 378 cases were printed, many dealing with multiple questions. About ten questions were answered in each issue, with the average response taking up less than a page, or about 100 to 200 words, although some covered several pages. Apparently readers liked the columns, for, in the second year of publication, an editor's note stated that "not less than 500 questions" had been received and that every effort would be made to respond to them. 11

In dealing with questions from readers, the reader's request was summarized in a short essential question (or questions) and then answered precisely and directly. Use of this "question-response" technique was not unique. It had been employed extensively and successfully by Ahmad Hassan, and, in fact, was his common method of dealing with questions concerning Islam. Throughout the period from 1925 to 1960, in the magazines Pembela Islam and Al-Lisaan, his books on religious issues, and in some of his interviews, he used "questionresponse" as he addressed issues confronting Muslims. ${ }^{2}$. His son, Abdulkadir Hassan, was now attempting in this set of cases to address problems facing Muslims, in keeping with the work of the father. The method of presentation undoubtedly seemed appropriate.

The answers to questions varied. In some cases technical answers were given. In others, however, matters were elaborated and traditional Muslim views were challenged. A good example is provided by case 155 concerning the use of a special prayer before Friday worship service.

(155) Meritorious prayer before Friday Communal Worship

Question: Is prayer meritorious before the Friday communal worship?

Response: The meritorious prayer which people of ten perform before

16. Khaidar Anwar, Indonesian: The Development and Use of a National Language (Yogjakarta: Bulaksumar, 1980).

17. Al-Muslimun 2, 3 (March 1955): 11.

18. Federspiel, Persatuan Islam, pp. 21-24. 
the Friday communal prayer is the performance of two prayer sets after the first call to prayer....

This sort of worship never existed in [early] Islam; neither the Prophet [Mohammed]--peace be on him and blessing--nor his Companions performed it or approved it.

People who maintain the existence of meritorious Friday prayer obviously have several justifications but none of these justifications are acceptable in the light of examination of firm religious sources.

Let [those who advocate this prayer] show if there is a firm basis for [this practice] from Religion [itself]. 19

This case speaks, of course, to the importance of preciseness in religious practice. Here the Persatuan Islam, in keeping with the traditional Islamic science of legal inquiry, holds that only practices clearly prescribed in religious sources are permitted. All other practices are innovation and an abomination to proper worship. A second case deals with a more complicated matter and a more elaborate response was given.

(136) The Call to Prayer using the Local Language

Question: Can the summoner to Friday communal prayer change the call from Arabic to the local language, because, according to our viewpoint, the bilal [summoner] is the leader of the congregation?

Response: [With the term] bilal, the petitioner certainly means adhan and iqama [i.e., the first and second calls to prayer].

[The person who] calls to prayer is not the same as the leader of a congregation, either in form or purpose, for several reasons, among them:

I. The call to prayer has a text defined for all time, while the [role of the] leader of a congregation is a temporal matter.

II. The call to prayer has a text defined for all time, while the congregational leader does not [have such a text], rather, it changes according to his need.

1II. The call to prayer is a matter for which an [eternal] reward is given to the person performing it, while the leader of the congregation has a temporal function ... . which has no relationship with the rewards of the Hereafter.

From the standpoint of religious teaching we are taught the call to prayer and commanded to utter it with the precise pronunciation which we have been taught. Such a matter is called a "religious matter," a matter of the "hereafter" or "worship." ...

Praying or worship is the province of Allah and His Prophet. Indeed it is [from these sources] that Religion receives its precise form and its characteristics.

As followers of the Islamic Religion, we are prone to fall short, exceed or alter matters of worship set by God and the Prophet. . . .

The basis for the preciseness [in this case] is the [tradition of the] Prophet [which states]:

"Anyone performing an act which is not commanded of him, is rejected."

Certainly the call to prayer is such an action.

19. Al-Muslimun 2, 6 (September 1955): 10 . 
Therefore the call to prayer which was taught by the Prophet ... cannot be changed to the local language.

This also applies in several other cases as well. . . 20

The differentiation made in this case between matters of worship ('ibadat) and temporal matters (perbuatan keduniaan) is unusual. As part of a worship ceremony it would seem to follow that it too is a matter of worship but the writer holds that its purpose actually is temporal since its contents are not prescribed or limited to matters of worship.

\section{Sual-Djawab: General Content}

The 378 cases cross a wide spectrum of subjects but there are perceptible trends in the material. For purposes of our investigation three general categories have been applied: religious belief, religious obligation and practice, and political and social matters. The summary of that categorization is found in Table 1.

Table 1. General Subjects Covered in the Sual-Djawab Section 21 by Year

$\begin{array}{cccccc} & 1954-55 & 1955-56 & 1956-57 & 1957-60 & \text { Total } \\ \text { Religious Belief } & 17 & 24 & 12 & 13 & 66 \\ \text { Religious Obligation and Practice } & 27 & 62 & 56 & 34 & 179 \\ \text { Social and Political Matters } & 46 & \underline{37} & \underline{29} & \underline{21} & 133 \\ \text { Total } & 90 & 123 & 97 & 68 & 378\end{array}$

Cases of religious belief consisted of matters of general information, questions of proper investigation into religious sources, application of belief to the Indonesian context, and compatibility of religious tenets to scientific and technological developments of the current age. The cases of religious obligation and practice dealt with ritual cleanliness, death and funerals, the poor tax, proper observance of prayer, fasting, and the pilgrimage to Mecca. The cases on social and political matters dealt with marriage and divorce, dietary issues, status of men and women, tolerance of non-Muslims, national law, and the national state. These categories, of course, are arbitrary, but do relate to the terminology used in the cases themselves. While many readers, particularly those in the West, might regard marriage and divorce, dietary issues, status of men and women, and tolerance of non-Muslims as religious, they are not regarded as such by the writers of Al-Muslimun. Rather, the writers see these categories as matters of social intercourse, in which Muslims are free to establish their own practices, except where God has set some limitations. The discussion under bid'a, below, where religious and nonreligious practice is defined, elaborates this point further.

The greatest number of cases fall in the area of religious obligation and practice, indicating a great deal of concern with proper observance of prayer and worship and general religious requirements. Even in the category of social and political matters, nearly half of the cases deal with traditional Muslim concerns regarding dietary regulations, and marriage and divorce matters.

20. Ibid. 2, 5 (August 1955): 6-7.

21. Sources, ibid, 1-5 (1954-60). 
On the other hand, twelve cases deal with science, medical practice, and technology, a comparatively small number considering that the issue of modernization was being nationally debated in Indonesia at this time. Political matters, particularly the role of Islam in the national state and national law, received considerable coverage in the early period--some eight cases in the first year-but this particular issue was not directly addressed in the last two years. Undoubtedly the advent of Guided Democracy made discussion of it a moot point and a political dangerous venture.

\section{Content of the Cases: Concepts and Specialized Language}

One way of examining the contents of the cases is to isolate key terms and analyze their meaning to Muslims as expressed through their use in the cases. The concepts selected for this study deal with three different, but interrelated matters: 1) terms used in applying religious principles to human behavior; 2) terms used in defining social relationships; and 3) terms used in defining political relationship. In the first category the concept "change" or "accretion" (bid'a) and five related terms of religious acceptability-"necessary" (wadjib); "meritorious" (hasan); "allowed" (halal); "reproachful" (makruh); and "forbidden" (haram) have been selected. These terms, common to Muslim jurisprudence and Muslim codes of behavior are used as a means of applying religious principles to human behavior. ${ }^{22}$ In social matters a set of five terms has been selected to show social distance between Muslims and other groups. The terms are "community of believers" (ummah), monotheists (ahli kitab), non-Muslims (orang jang bukan Islam), "unbeliever" (kafir), and "heathen" (musjrik). The third category deals with political matters, and, as such, contrasts "divine law" (shari'a) with "man-made law" (undangundang).

a. Terms used in applying religious standards. Perhaps the key term for the writers of Al-Muslimun in responding to the questions of the readers is bid"a, a religious term of Arabic derivation. In a case entitled "Definition of bid' $a, "$ the writer states that bid'a in general ... means: "Something that is new, ereating something ... such as electricity, radio and so forth, which had not existed previously." 23 It can have a neutral or even a beneficial meaning, but in religious matters the definition is negative. In matters of worship, bid'a is an action which adds to the principles of religion. When the new action (bid'a) is first undertaken, those who perform it believe that the action is properly part of religion, even though, in reality it is not. The writer further notes that such pseudo-religious practices were installed by religious authorities in the past to introduce into religion many special elements which they believed were beneficial and meritorious. ${ }^{24}$ The viewpoint of the author is that such change is not to be countenanced in religious matters. The measure for determining whether behavior is actually part of religion or an accretion is whether it was commanded by God in the Qur'an or practiced

22. These six terms, given here with their Indonesian equivalents, have approximately the same meaning as the Arabic words despite the different script. The same is true for "unbeliever" and "heathen" later in the paragraph. The Arabic equivalents are not given, as they would be repetitious of the Indonesian words.

23. Ibid. 2, 3 (June 1955): 7.

24. Ibid.: 6-7. 
by the Prophet as recorded in the Traditions. If it fails this two-way test, it is bid'a, an unacceptable accretion. The basis for this view is a tradition of the Prophet in which he states that "bid'a is error and belongs in the fire." 25 Consequently it can be said that bid'a, well intentioned or not, has no place in religious matters. In secular or temporal matters, however, change is acceptable unless religious sources specifically reject such change. The discovery of technical instruments and medicines, which have been beneficial and are not at odds with religious principles, are cited as examples. On this basis, in many cases the writers repeat the principle that action regarding religious activity is permitted only when expressly commanded by the key religious sources and that, in matters of nonreligious earthly behavior, all actions are permitted except those expressly forbidden by religious authority.

It remains, then, only to decide whether or not a matter concerns religion. At this point, several key categories appear. Included in religion are all matters connected directly with worship. The language of worship, except the Friday sermon, must be in Arabic. The call to worship may not be altered to suit local custom. Adding extra phrases to prayers as a sign of piety is not permitted. 26

The principle of religion extends to the funeral and particularly to the gravesite, where behavior is seen as involving worship. Consequently, extra activities of ten prescribed in the Muslim books of jurisprudence (Ar: fiqh) are regarded as unacceptable accretions. Specifically addressed are the last prompting (talqin) in which the deceased is given instruction to help him answer the questions of belief that the angels of the grave will ask him to determine whether he is truly a believer. Another case expresses the view that common Islamic recitation formulas--the dhikr and tasbih--and any special readings from scripture, such as the Surah Jasin, also cannot be justified, in that they are not commanded. 27

The area of rival religious values also is viewed as involving worship. The use of amulets and charms is not permissible, not because they are ipso facto wrong, but because the Qur'an and Traditions do not enjoin their use. In the matter of holding a slametan (ritual meal) during an eclipse of the moon, the writers find that, since there is a worship ceremony for such an occasion, to add a slametan would be to add uncommanded behavior to a religious ceremony. On this point, however, the question specifically addresses the situation in which the ritual meal is added to the prayer. The issue of a slametan by itself is not addressed. In another case a reader asks about cutting the hair of an infant and having a kenduri (ritual meal) as part of the proceedings. The reply: "As for holding a kenduri religious observance ... [it has] no basis in religion." 20 The writers turn aside the practice of consulting a soothsayer (dukun), stating that belief in mystical matters does not have a basis in religion and cannot be used by Muslims. 29 On such matters, where the force of custom or the popularity of the action contribute to its use, the author states forcefully: "Religion does not look to the great

25. Ibid.: 7 .

26. Ibid. 2, 12 (March 1956): 6-7; 2, 5 (August 1955): 7.

27. Ibid. 2, 7 (October 1955): 9-10; 2, 2 (May 1955): 4 .

28. Ibid. 3, 1 (April 1956): 210, 214-15.

29. Ibid. 3, 30 (August 1957): 10-11. 
majority of people or to religious authorities ... but to the principles from God and His Prophet." 30

In areas of behavior regarded by the writers of Al-Muslimun as temporal affairs there is a complex group of prohibitions and commands. The writers note that food and eating belong to this category and that pork may not be eaten, as it is forbidden by religious sources, but that dog may be eaten because it is not expressly prohibited. They note that all sports are permitted and that music as well fits in this nonreligious category. Tattooing is forbidden, while nearly all matters of commerce and trade are permitted. As noted above, even the Friday sermon, as distinct from the worship service itself, is seen as a temporal matter. The sermon is prescribed by religion but the contents are not regulated and may deal with whatever matters the speaker to the congregation wishes. ${ }^{31}$

The second concept in this category is a set of terms defining behavior by Muslims in particular situations. Here the five-fold category common to Muslim schools of law is used--"necessary," "meritorious," "permitted," "reproachful," and "forbidden." 32 Usually the matters fall into necessary, permitted, or forbidden, and it is seldom that meritorious and reproachful are used. As we have seen in the section on bid'a, matters of religious performance which are necessary (wadjib), include prescribed prayer, giving the alms tax, and fasting during Ramadan. Likewise some actions, usually in nonreligious matters, are forbidden (haram), such as drinking alcohol. A large number of matters are permitted (halal), such as working with a non-Muslim, undertaking business activities, and participating in sports. The category of "meritorious" (hasan) is more circumscribed, but some actions are listed, such as praying at night. The category of "reproachful" (makruh) is similarly circumscribed, including only one immediate example when certain categories of meat are discussed, such as "wild animals, snakes and tigers." 33 Readers are admonished that analogy should not be used to make "reproachful" into "forbidden" matters, such as, "one may not eat dogmeat because it equates to pork," or making meritorious into "necessary" matters because they seem good, such as extra recitations of Surah Jasin (102). ${ }^{34}$ Categories exist as God sets them, not as mankind would like to have them.

b. Social concepts. Any discussion of social vocabulary must start with the concept of community of believers. Once this has been elaborated, Muslim perceptions of other groups in society then become clear, being placed in an understandable context. In this elaboration, then, an examination will be made of the social distance between Muslims and four other identified groups: other monotheists (ahli kitab), non-Muslims (orang jang bukan Islam), nonbelievers (kafir), and heathens (musjrik). The cases deal extensively with these various groups and Muslims' relations with them.

The community of believers (ummat) receives no special attention as a concept and in no case is a precise definition given. The term is used occasionally

30. Ibid. 2, 2 (May 1955): 4.

31. Ibid. 1, 8 (November 1954): 5-6; 1, 10 (January 1955): 9; 2, 9 (December 1955): 11; 2, 2 (June 1955): 5-6; and 3, 29 (August 1956): 5.

32. See above p. 62. Case 70 in Al-Muslimun 1, 10 (January 1954): 7-8, outlines these classifications.

33. Ibid. 1, 10 (January 1954): 6-7.

34. Ibid. 2, 2 (May 1955): 4. 
by both petitioners and writers and seems to possess known implications for both sides. The term is used to fit with general Islamic thinking, wherein those who confess Islam and identify with the religion are regarded as belonging to the community. There is no attempt to differentiate the general follower (Ar: Muslim) from the true believer (Ar: mu'min), so the community includes both the casual and dedicated follower.

But if a definition is not given, the principle of responsibility for community action and behavior is both implied and carefully elaborated in a number of cases. This is clear in Case 11 when the writer advises that anything that relates to mystical practice or forms a kind of worship "may never be practiced by the community of Islam," unless there is a clear command of God and His Prophet to do so. ${ }^{35}$

Another case deals with specific instances. Case 22, concerning the alms tax incumbent on all Muslims, outlines some of the basic obligations that seem to be covered by the term "in the way of God" and for which alms may be given. Since many of these obligations cannot be undertaken by individuals, there is an implication that they are the community's responsibility. These include "the study of knowledge, undertaking the pilgrimage, shrouding the dead, constructing bridges, building fortifications, enriching mosques, developing foodstuffs and water in the countryside, building health facilities, establishing hospitals, sending out Islamic missionaries, covering the operating expenses of mosques and their teachers, and various other matters of benefit and public importance which are acknowledged by God." 36

In Case 70, titled "respecting religion," the writer warns Muslims not to depart from their religious obligations for other enticements or even other obligations, such as momentary feeling, psychological justifications, conformity with custom (adat), political position, circumstance or situation, or family obligations, except when permitted to do so under conditions of danger, where survival is threatened. The case concludes with some direct warnings about the plight of the Muslim community in Indonesia and offers advice on what Muslims must and cannot do. Pointedly the author states that it is obviously rather difficult to define the means for influencing the public so that religion is respected, especially in a country like Indonesia where Islam is not a popular religion (dimana Islam tidak mendjadi Agama Ra'jat), a situation made worse by the antireligious efforts of those who want to divide the unity of Islam. "But if, among us, the majority want to persuade people to accept Islam so that it has no rivals, want to preach everywhere, want to teach the genuine picture of religion, want to increase the number of religious books in circulation, educate people not to imitate blindly," then they will make an impression on the general populace. But, if on the other hand, Muslims remains ignorant and adopt passive attitudes, then the greatness of the Islamic community will be lost. ${ }^{31}$

In Islamic history a great deal of stress has been placed on Islam's relationship with other believers of monotheism, the so-called "People of the Book (ahli kitab), a term generally applied to Christians and Jews. Writers of Al-Muslimun reflect that position, and in three cases they spell out a relationship of general tolerance and acceptance. In Cases 146 and 271, marriage

35. Ibid. 1, 2 (May 1954): 9-10.

36. Ibid. 1, 4 (July 1954): 8-12.

37. Ibid. 1, 10 (January 1954): 8. 
between a Muslim male and a Jewish or Christian woman is permitted, and it is explicitly stated that conversion of the woman to Islam is not a precondition. 3 s The basis for the view is the record of behavior of the Companions of Mohammed, some of whom married Christian and Jewish women. In a third case, dealing with a Muslim working in a church, the response noted that a Muslim taking part in a worship service of the church would be considered an unbeliever, but that general work there is not forbidden. The writer questioned, however, the appropriateness of a Muslim choosing to work in such a situation, even though it is not forbidden. 39

Only one case specifically concerns dealings with non-Muslims. In Case 230 it is stated that a Muslim may undertake a business venture with a non-Muslim. The Muslim's portion of the business would be subject to the Muslim's alms-tax while the part belonging to the nonbeliever would not.40 On the other hand, the terms "unbeliever" and "heathen" are of ten referred to in the cases and a very negative view emerges. The cases on heathens generally identify Chinese as belonging to that group, while Communists and some nationalists are identified as unbelievers.

In Cases 9 and 85 a definition is given of an unbeliever (kafir). The writer explains that the term denotes a person who does not believe in Allah and the other things that Islam commands to be believed, "such as the existence of God or ... the Justice of God." The case notes that there are various kinds of unbelievers. "There are those who do not want to aceept or believe, such as Marx, Lenin, Stalin and [other] Communists." A second group, named hypocrites (munafiq), hide their disbelief and profess belief. They make a pretense of confessing Islam, but their intention is to confuse Muslims, "as the P.K.I. [Indonesian Communist Party] does." A third type of unbeliever is one who truly knows the truth of Islam but does not want to recognize it, "such as Mr. Hardi" (at the time, leader of the Indonesian Nationalist Party). The last variety is based on adamant denial, such as Satan (Iblis) himself, who knows of the existence of God but refused to say so openly. The case ends with the admonition that the ultimate fate of all unbelievers is in the fires of hell. 41

The view that some unbelievers, especially Communists, are deceitful is further elaborated in Case 92, which deals with the question of whether a person confessing to be a Muslim should be taken at his word. The petitioner specifically questioned the validity of a marriage, performed by a Muslim mosque official, wherein the groom was a member of the Communist Party and the bride was a Muslim. In this particular case the mosque official (pengulu) asked the prospective groom to recite the Islamic confession (sjahadat), which he did, and, on that basis of identification with Islam, the official undertook the Islamic marriage ceremony. The response notes that belonging to the Communist Party and being a Muslim are incompatible, since the Communist Party is dedicated to principles that are antireligious and against Islam. Anyone associating with the Party aids its disbelief and is an unbeliever. Only by leaving the Party can this association be voided, and it is only when this has been done that the former member should be married in a Muslim ceremony. The writer

38. Ibid. 1, 5 (August 1954): 4; 3, 33 (November-December 1957): 5-6.

39. Ibid. 1, 10 (January 1954): 5 .

40. Ibid. 3, 27 (June 1956): 7.

41. Ibid. 1, 2 (May 1954): 6-7; and 1, 12 (March 1956): 7-8. 
concludes that mosque of ficials should rigidly question those suspected of belonging to the PKI and perform marriage ceremonies for them only if they have left the Party. ${ }^{12}$

In a third case dealing with communism, the writer responds to a petitioner who asked whether a particular verse from the Qurian was fitting to be used as a basis for combatting communism. In stating that Muslims are free to reply to PKI distortions concerning Islam, the response draws on a wide range of Qur'anic verses which invoke the use of spiritual effort (Ar: jihād). The term for actual fighting, as in armed conflict, is to be employed when an enemy attacks Islam and the defense is to be undertaken by a Muslim army, not by individual groups of Muslims. ${ }^{43}$ In this sense the writer recognizes some limits on a Muslim's conduct towards his political enemies.

Association and dealings with heathen (musjrik) are described in less hostile tones than those with unbelievers. In Case 217 the writer notes that some Muslims do not want to have much to do with the Chinese, because they eat pork and are described as "doing evil and pernicious things." He rejects this view, saying that normal business relationships between Muslims and Chinese are quite acceptable. However, close social relations should be avoided and Chinese contributions to a mosque would not be proper. ${ }^{44}$ In Case 283 the writer expresses the opinion that meat slaughtered by Chinese is unacceptable for use by Muslims because Traditions note that slaughtering for Muslim use must be done by either a Muslim or a monotheist who pronounced "in the name of God" (bismillah) as the slaughter takes place. ${ }^{\mathrm{s}}$ While in expressing this view the writer denies holding any animosity towards the Chinese, certainly the refusal to consider using meat or accepting contributions from them indicates that it is preferable to maintain a distance from the Chinese.

c. Political concepts. Political thinking in the cases is conveyed through the concept of law expressed in the terms shari'a and undang. The definitions, use of the terms, and the range of situations covered deal precisely with the differences in Muslims' obligations towards their religion and towards the Indonesian political state. Without doubt the two loyalties are difficult to reconcile, even though the writers of Al-Muslimun attempt to do so. Their conclusion that religious must be above state law was at odds with the government claim regarding the supremacy of national law.

The term shari'a is used sparingly, but, when employed, it is with the understanding that it is a basic principle that needs no great explanation. In Case 59 on surrogate mothers and Case 95 on polygamy, the term shari'a is used in this sense. Shari" $a$ is seen in the first case as the "exact" or "firm" law (hukum jang tegas). 4 A fuller explanation is offered in the second case in answer to the question of whether, because of changed conditions, the law of polygamy in Islam might change also. In his explanation the author notes that, to answer the question, he must outline the difference between the shari'a and laws which are instituted by man. "Laws (undang-undang) are made by man; the shari'a is from God." Since man is weak and deficient, then the laws

42. Ibid. 2, 1 (April 1955): 5-6.

43. Ibid. 1, 10 (January 1955): 4.

44. Ibid. 3, 25 (April 1956): 10-11.

45. Ibid. 3, 34 (January 1958): 8-10.

46. Ibid. 1, 9 (December 1954): 10; 2, 1, (April 1955): 7-8. 
he institutes will be weak and deficient and, accordingly, his laws will need changing. This is not the case with the shari'a, for one of the attributes of God is "complete knowledge of whatever will ever exist." Accordingly, his shari'a is applicable to all time. "The shari'a of God is permanent and non-changing." 4

These explanations indicate that the term shari'a is used in a classical Islamic sense as the holy law with its exact form known only to God, and it thus can only be approximated by mankind. The basic principles are known to man, as revealed by God through prophets, and mankind must seek to put those principles into effect so that the community can strive to conform with this holy order.

The translation of the shari'a to man-made law is addressed in several cases. First, in line with the modernist Muslim position, the claim of the classical Muslim schools of law to have incorporated the shari'a in their law codes is rejected on the basis that no command in scripture points to the schools of law as the repository of divine law. In a rather lengthy series of arguments, not germane to this particular presentation, the writer rejects the various arguments for following the codes of jurisprudence put forth by those schools, is At the same time, the writers of Al-Muslimun use the science of examining scripture employed by the founders of the schools of jurisprudence, and that science--Ușul al fiqh-is outlined in a special series of articles in Al-Muslimun alongside the Sual-Djawab section." "

The case for Islamic principles, rather than jurisprudence, is outlined succinctly in an unnumbered entry (between 120 and 122) titled "The Matter of Responsibility." The writer notes that responses to questions from readers are derived from the "verses of the Qur'an, the Traditions, the stories (of the companions)," and other sources. In context, however, it is apparent that matters of principle draw only on the first two sources and the other sources have validity in amplifying the Qur'an and Traditions, but are almost never original sources in their own right. The case also acknowledges "independent investigation" (ijtihad) as a valid tool for locating religious principles and applying them to contemporary issues. 30 The editors view the application of such principles as consistent with their attempts to approximate the shari'a.

Independent investigation has been widely heralded, by Muslims and observers of Islam alike, as the tool for liberating Muslim scholars from the fetters of stagnant thinking. As indicated by the writers of Al-Muslimun, however, independent investigation does not change any of the rules for examining and using religious sources, but merely allows the investigator to ignore the previous interpretations in formulating a new one based on his own investigation. Previous interpretations, particularly those of the highly heralded jurists of the classical period, may be used for guidance. While ijtihad has been a useful tool for changing attitudes in some areas, such as health and medicine, and somewhat in banking, it has of ten imposed even further restrictions, particularly in funeral practice and conformity with a region's cultural mores. This is

47. Ibid. 2, 1 (April 1955): 7-8.

48. Ibid. 1, 9 (December 1954): 4-9.

49. Abdulkadir Hassan, Ushul-Fiqh (Bangil: Persatuan Islam, 1956), as serialized in Al-Muslimun 1, 1 (April 1954) - 5, 45 (December 1960).

50. Ibid. 2, 4 (July 1955): 4-5. 
also the case with Al-Muslimun's writers. They do review all the sources anew--and seem to be very thorough. The result is frequently, however, an insistence on more restrictions on Muslim conduct than observed by those holding to the old interpretations and rejecting ijtihad as heresy. The writers of Al-Muslimun, of course, see this as evidence that the new interpretation is needed as a means of fortifying religion and bringing practice into closer conformity with the ideals of Islam. 31

The second concept, undang-undang, denotes law made by human society. Case 87 "According to National Law" (Menurut Undang-Undang Negara) addresses this directly in the question: "Every nation dispenses justice according to its various laws: What is the ruling?" The response notes that Islam recognizes laws dealing both with worship and with temporal matters. Muslims cannot avoid the necessity of obeying the laws of their religion since these are obligatory not optional. National laws which do not have an Islamic form may be observed by Muslims if they do not conflict with the commands or requirements of Islam. The response concludes that, if these laws conflict with the tenets of Islam, it is forbidden to obey them. The view is based on a Tradition of the Prophet that states that "We may not obey man in rebelliousness to God; only in obeying what exists in goodness." 32

A great deal of attention is given in the early cases--those between 1955 and 1957 when the issue was being debated nationally--to the importance of making national law compatible with the sharia. As if to leave no doubt in the minds of the readers of Al-Muslimun about the editors' view on the matter, the very first case deals specifically with this issue. It bears the title, "Joining Parties other than Islamic Parties." The opening statement of the response pointedly notes that "in several verses of the Qur'an God commands [Muslims to] follow God's laws alone, whether in everyday life or in regard to the state." A person who does not want to follow the laws of God or does not want the institution of the laws of Allah ... is called a sinner (fasig), a wrongdoer (zhalim), and an unbeliever (kafir). Al-Maidah 2 is used as the justification of this position. ${ }^{33}$

Two other cases further explain the use of law in a nation. In Case 45, dealing with capital punishment, the writer notes that Muslims must distinguish between laws based on Islamic principles and those based on other criteria. When a government uses punishments identical to those propounded by Islam without intending to do so, this is not the same as following the laws of God, it merely conforms to those laws. The writer notes that intention is important. "We, the Community of Islam, are never satisfied with laws that accidentally fit with the laws of our religion."TR In Case 202 a petitioner asks about a specific case where a person who killed someone was sentenced to prison, presumably by an Indonesian court. The response is that the sentence was not consistent with Islam, since a verse of the Qur'an (Al-Baqarah 178) commands that those who kill be killed in turn. The writer notes that a lighter sentence may not be imposed since the sentence is clearly stated in the Traditions

51. For a discussion of ijtihad in contemporary times elsewhere in the Muslim world, see John Obert Voll, Islam: Continuity and Change in the Modern World (Boulder: Westview Press, 1982), pp. 83-86, 224-25, and 251-52.

52. Al-Muslimun 1, 12 (March 1955): 9.

53. Ibid. 1, 1 (April 1954): 4.

54. Ibid. 1, 7 (October 1954): 8 . 
of the Prophet. He warns that not to follow God's command constitutes sin (dosa).ss While not criticizing the government directly, the case makes it clear that the author finds Indonesian national law inconsistent with his concept of a divine law. In a final case, however, the writer warns that Muslims are not themselves free to inflict the punishments ordered by God for certain crimes. In Case 60 he specifically states that "in an Islamic state, as well as in other states, it is not right for the people to become judges themselves," but, rather, it is the responsibility of specifed organs of the national state. 36

This discussion clearly contends that Muslims have an obligation to use Islamic principles and laws in the governing of a state. If the laws are not in place Muslims are not, under normal circumstances, to take it upon themselves to apply the punishments prescribed by the shari'a when the state fails to do so. Muslims certainly must regard non-Islamic laws and decisions as wrong and recognize that they should be replaced by Muslim laws and decisions when Muslims, exerting their best efforts, are able to do so. 37 There is no argument for immediacy, as was the case with the Darul Islam in 1948, when one stated reason for its attempt to establish an Islamic State of Indonesia was to apply religious law. The position of Al-Muslimun, then, was consistent with that of other Muslim organizations, such as the Muhammadijah and the Nahdatul Ulama, which also worked for the eventual establishment of Islamic law, but who were willing to settle for less temporarily. s*

\section{Sual-Djawab: Religious Authority}

The sources of religious authority the writers use in responding to the cases are consistent with the call to employ principles from Muslim scriptures. Table 2 outlines these sources, Each year between 25 percent and 41 percent of the cases contain references to the Qurian, and well over half the cases cite Traditions. Actually, over 80 percent of all cases for the entire period use references to Qurtan and Traditions. This approach is consistent with the modernist, fundamentalist position of the Persatuan Islam which emphasized those two sources as the primary repository of Islamic principles. Moreover, the writers demonstrate a rich knowledge of those sources, particularly when they draw on the traditions, where over twelve separate collections are employed in 600 references. ${ }^{39}$ While some readers might quarrel with the selection of a particular verse in a given case, the scriptural quote is always germane

55. Ibid. 2, 12 (March 1956): 8 .

56. Ibid. 1, 9 (December 1954): 10-11.

57. Ibid.

58. On the Darul Islam's pronounced views, see Karl D. Jackson, Traditional Authority, Islam, and Rebellion (Berkeley: University of California Press, 1980), pp. 84-86. A full study of the views of Darul Islam villagers toward religious values is given on $\mathrm{pp} .98-128$.

59. The compilers, with frequency of use in parentheses, are: Muslim (131), Bukhārī (101), Ahmad (81), Abū Dāwūd (70), Nas ḡî̀ (41), Ibn Ḥadjar (35), Tirmidhī (32), Salämallah (24), Ibn Qudāmah (23), Hākim (22), Ibn Madjāh and Baihaqĩ (20). A discussion of the compilers is found in H. A. R. Gibb and J. H. Kramers, Shorter Encyclopedia of Islam (Leiden and London: Brill and Luzac, 1961), pp. 116-20. 
to the issue under discussion. Moreover, the scripture is nearly always quoted first in Arabic, followed by an Indonesian translation. This approach is consistent with the orthodox Sunni Muslim position that in matters of doctrine the Arabic text of the scripture should always be used. Supplying the translation is consistent with the modernist Muslim position that even Muslims who are ignorant of Arabic should have an opportunity to understand in their own language the general meaning of any Islamic text.

Table 2. Percentage of Various Sources Used in Cases ${ }^{\circ}$

$\begin{array}{lccccc} & 1954-55 & 1955-56 & 1956-57 & 1957-60 & \text { Average } \\ \text { Qurian } & 41.5 \% & 32.1 \% & 20.4 \% & 25.0 \% & 29.4 \% \\ \text { Traditions } & 53.9 & 65.1 & 57.1 & 57.3 & 58.0 \\ \text { Islamic Religious Sources } & 12.4 & 16.0 & 11.2 & 16.1 & 13.6 \\ \text { Previous Entries } & 4.5 & 14.2 & 5.1 & 2.9 & 7.2 \\ \text { Authors of Persatuan Islam } & 3.8 & .8 & 1.0 & 11.7 & 3.4 \\ \text { General Islam } & 5.6 & 2.6 & 5.1 & 2.9 & 4.0 \\ \text { No reference } & 7.8 & 6.2 & 17.3 & 16.1 & 11.2\end{array}$

( $N=388$ cases with several different sources used in many cases.)

Other sources are used as well. About twenty-five cases employ classical and modern sources on Islamic jurisprudence, ranging from the highly respected classical legal theorist al-Nawäwi to the modernist Syrian commentator Rashĩd Ridä. In about twelve cases this set of sources is supplemented by reference to works by members of the Persatuan Islam. In contrast to the scriptural references, however, these sources are used to support interpretation of scripture or as references for further information. By using these contemporary writings, the authors set themselves apart from those who follow the schools of jurisprudence, since traditional Muslims would rely heavily on previous interpretations to provide the correct answer to the issue under discussion.

A small number of cases use the general term "Islamic principles" without elaboration of just what those principles are, or listing a scriptural text. No source is used in 11 percent of the cases, where further elaboration seems unnecessary because of the nature of the answer.

Striking is the lack of other Indonesian sources, particularly from the Indonesian Muslim community, on the same subject. Undoubtedly this emphasis reflects a view that Islamic scriptures are timeless and that current literature would not add significantly to any discussion at hand. The editor verifies this position in an editorial note where he states that scripture must be the source of the responses and that the use of other views is to be avoided.61

The pattern on the use of sources is extremely narrow and reflects a cultural bias against those in Indonesian. Undoubtedly this reluctance to use other Indonesian sources is explained in part by doctrine and is not necessarily an evidence of cultural bias. The writers are interested in basic religious sources which, in their view and that of nearly all modernist Muslims elsewhere in the Muslim world, must be used in the original Arabic for accuracy. Consequently Indonesian writings on these subjects would not be usable. However, a cultural bias toward Arabic writings does seem apparent in some texts used

60. Sources, Al-Muslimun, 1-5 (1954-60).

61. Al-Muslimun 2, 5 (August 1955): 4. 
to elaborate principles. Here, Arabic sources are almost always relied on, while the elaborations of Indonesian Muslims on the same subjects are ignored. There was no absence of Indonesian sources at the time on any of these matters, and a series of writings had dealt with significant issues over the previous fif ty years which certainly were known to the editors of Al-Muslimun. Hasbi Ash-Shiddieqy's elaboration on the acceptability to Islam of blood transfusions and Agus Salim's justification of socialism are two significant examples.62 Even the pioneer work of Ahmad Hassan, the most respected writer in the Persatuan Islam, is largely ignored in this context. The primary cause of these omissions seems to have been a confusion between primary sources and elaboration, and the result was to ignore a rich tradition in Indonesian that could have been drawn on for comparison.

\section{Conclusions}

In reviewing the hypotheses presented in the introduction, our examination shows that Al-Muslimun is closely associated with Islamic values generally found in Middle Eastern Islam.

1. "Enunciation of Islamic Principles...." The examination shows that the principles of Islam as expressed in the standard books on Islam are reflected in the responses given to the questions presented by readers. The cases are replete with references to God and his word, the Qur'an, to the Prophet Mohammed and the record of his words and acts (Traditions), and to the standard articles of faith and obligations for all Muslims. Much of the material speaks to the Indonesian context, and every attempt is made to apply Muslim standards to the Indonesian environment.

2. "Use of Arabic. ..." Arabic expressions, names, and scriptural quotations are used extensively in the cases. In particular there is a heavy use of Arabic religious terms and frequent quotation of religious sources to support the positions taken in responding to concerns of readers.

3, "Attempts to place Islamic principles into everyday life. ..." There is a heavy emphasis on the importance of Islam in everyday life. Indeed the purpose of presenting the cases is to accomplish that goal. Religious activity, or at least concern with religion in the performance of all activity, is seen as the proper concern for Muslims. Worship in all its aspects is regarded as a necessary emphasis in life, while all other behavior is to be kept consistent with religious principles and should never transgress the limits set by religion.

4. "Non-recognition or condemnation of other viewpoints. . .." Attitudes towards political enemies and certain non-Muslims are expressed sharply. The Communists and nationalists are regarded as, at worst, enemies of God and, at best, sinful, while the Chinese are viewed as heathen and beyond the pale of spiritual salvation. Distance from such creatures is recommended.

62. K. H. Moehammad Hasbi Ash-Shiddieqy, Pemindahan darah dipandjang dari sudut hukum agama Islam (Jakarta: Bulan Bintang, 1954); Hadji Agus Salim, "Kemadjuan Perkara harta," in Djedjak Langkah Hadji A. Salim (Jakarta: Tintamas, 1954), pp. 19-22. 
It is apparent from the foregoing study that Al-Muslimun can act as one model for measuring conformity with Middle Eastern perceptions of Islam and can be used as a marker in that regard. Obviously other valid models exist, some perhaps more cognizant of the Southeast Asian environment, that would challenge Al-Muslimun's views within a Muslim context. Nevertheless, Al-Muslimun's identification with Islam can be seen as intimate and genuine. 